\title{
Оцінка колекційного фонду рослин роду Dahlia Cav. у Кременецькому ботанічному саду
}

\section{Ольга Берідзе, Ірина Ковальчук}

Кременецький ботанічний сад, Кременець, Україна

Адреса для листування: kovalchukolja@ukr.net

Отримано: 04.05.19; прийнято до друку: 06.06.19; опубліковано: 28.06.19

Резюме. У статті здійснено оцінку колекційного фонду роду Dahlia Cav. Кременецького ботанічного саду. Мета роботи - аналіз колекційного фонду роду Dahlia Cav. Кременецького ботанічного саду, оцінка декоративних показників та опрацювання головних напрямів збагачення, утримання колекції й подальше впровадження в озеленення. В основу роботи покладено матеріали інтродукційних досліджень 2018 р. Фенологічні спостереження проведено за загальноприйнятою методикою в ботанічних садах.

В Україні вона відома 3 кінця XVIII ст. Починаючи з 50-х років XIX ст., дослідження розпочали в Національному ботанічному саду ім. М. М. Гришка НАН України. На сьогодні вивченням сортів роду Dahlia займаються Г. Музичук, А. Дорошенко. Колекція нараховує 231 сорт.

Колекцію жоржин у ботанічному саду Львівського національного університету ім. Івана Франка започатковано в 70-х рр. минулого сторіччя. Основним джерелом отримання сортового матеріалу були ботанічні сади Білорусі, Прибалтики, м. Києва та Москви, Польщі. На сьогодні колекція жоржин становить 107 сортів, дослідження проводять Я. А. Федоровська, А. І. Прокопів.

Оскільки такі дослідження в Україні $\epsilon$ фрагментарними, уважаємо актуальним вивчення та оцінювання декоративних ознак представників роду Dahlia у Кременецькому ботанічному саду. Інтродукцію цього роду розпочато з 2017 p.

Для оцінки сортового розмаїття колекційного фонду жоржин використано аналітично-порівняльний метод. В аналізі колекційного фонду дотримувалися садової класифікації жоржини, розробленої М. П. Ященком.

Наведено результати щодо розподілу рослин за групами. Відображено сорти колекції за головними кольорами: червоний $(\mathrm{R})$ наявний у трьох культиварів різних садових груп, оранжевий (Or) - y восьми, темно-червоний (DkR) - в одного сорту, лавандовий, фіолетовий (L) - у двох, рожевий (Pk) - y двох, двоколірне забарвлення (Bi) мають вісім сортів, біле (W) - один, жовте (Y) - два, темний бленд (LB i DB) - два сорти. Досліджені сорти жоржин $є$ перспективними для вирощування в умовах культури. Поповнення колекції роду Dahlia залишається основним завданням науково-колекційної роботи як способу збереження й збагачення рослинного різноманіття. Використання жоржин під час озеленення території дачної ділянки відіграє значну роль для досягнення запланованих декоративного та естетичного ефектів.

Ключові слова: Dahlia Cav., культивар, садова група, Кременецький ботанічний сад, колекція.

\section{Evaluation of Collection Stock of Plants of the Genus Dahlia Cav. in the Kremenets Botanical Garden}

\section{Olga Beridze, Irina Kovalchuk}

Kremenets Botanical Garden, Kremenets, Ukraine

Correspondence: kovalchukolja@ukr.net

Abstract. The article reports on the evaluation of the collection stock of the genus Dahlia Cav. Kremenets Botanical Garden. The purpose of our work was the analysis of the collection fund of the genus Dahlia Cav. Kremenets Botanical Gardens, estimation of decorative indices and processing of the main areas of enrichment, keeping the collection and further introduction into landscaping. The basis of the work is the materials of the 
introduction studies of 2018. Phaenological observations were conducted according to the generally accepted methodology in botanical gardens.

This methodology is known in Ukraine since the end of the eighteenth century, beginning with the 1950s. The study was started at the National Botanical Garden named after. M. M. Grishko National Academy of Sciences of Ukraine. Currently, the study of varieties of the genus Dahlia are G. Muzychuk, A. Doroshenko, the collection has 231 cultivars.

Collection of daisies in the botanical garden of Ivan Franko Lviv National University was founded in the 70's of last century. The main source of cultivar material was the botanical gardens of Belarus, the Baltic states, Kyiv and Moscow, Poland. Today, the collection of daisies has 107 cultivars, the research is carried out by J. A. Fedorovsky, A. I. Prokopov.

Since the research data in Ukraine are fragmented, the study and evaluation of the decorative features of the Dahlia species in the Kremenets Botanical Garden is relevant. The introduction of this genus began in 2017.

An analytical-comparative method was used to estimate the cultivar diversity of the collection stock of daisies. In the analysis of the collection fund, the garden classification of dahlias, developed by M. P. Yaschenko was used.

The results of the distribution of plants in groups are presented. The cultivars of the collection are depicted in the main colors: red (R) is available in 3 cultivars of various garden groups, orange (8), dark red (DkR) in 1 varieties, lavender, purple (L) 2, pink ( Pk) in 2, two colors (Bi) have 8 grades, white (W) 1, yellow (Y) 2, dark blend (LB and DB) have 2 varieties. The investigated cultivars of daisies are promising for cultivation in culture. Replenishment of the collection of the Dahlia genus remains the main task of scientific and collegial work as a way of conservation and enrichment of plant diversity. The use of daisies during the landscaping of the territory of the country estate plays a significant role in achieving the planned decorative and aesthetic effects.

Key words: Dahlia Cav., Cultivar, garden group, Kremenets Botanical Garden, collection.

\section{Вступ}

За даними класифікаційної бази «Тhe Plant List», нараховується 39 дикорослих видів: D. apiculata Sherff, D. atropurpurea Sorensen, D. australis Sherff, D. brevis Sorensen, D. campanulata Saar et al., D. cardiophylla S. F. Blake \& Sherff, D. congestifolia Sorensen, D. cordifolia McVaugh, D. dissecta S. Watson, D. dumicola Klatt, D. excels Benth, D. foeniculifolia Sherff, D. hintonii Sherff, D. hjertingii Hansen \& Sorensen, D. hortensis Guillaumim, D. imperialis Roezl, D. lehmannii Hieron, D. macdougallii Sherff, D. maximiliana Hort., D. maxonii Saff., D. merckii Lehm., D. mollis Sorensen, D. moorei Sherff, D. neglecta Saar, D. parvibracteata Saar \& Sorensen, D. pinnata Cav., D. pteropoda Sherff, D. purpusii Brandegee, D. repens Hartw. ex Benth, D. rudis Sorensen, D. rupicola Sorensen, D. scapigera Dietr., D. scapigeroides Sherff, D. sherffii Sherff, D. sorensenii Hansen \& Hjert., D. spectabilis Saar \& Sorensen, D. tenuicaulis Sorensen, D. tenuis Robinson \& Greenm, D. tubulata Sorensen [1]. Жоржини, що культивуються, відносять до виду жоржини культурної або мінливої (Dahlia cultorum Thorsr. et Reis.) [2]. Зазначена вище класифікація досить складна. Тому в 1962 р. у Брюсселі під час проведення міжнародного садівничого конгресу створено міжнародну класифікацію, за якою сорти жоржини культурної залежно від виповнюваності кошиків, типу й форми квіток поділено на 10 класів: немахрові, анемоноподібні, комірцеві, піоноподібні, декоративні, кулясті, помпонні, кактусові, напівкактусові, перехідні (змішані) [1]. Сьогодні до зазначених класів жоржини додатково приєднано прості, німфейні, розсічені та міньонні. Як декоративну рослину жоржину почали використовувати в Свропі з 1575 р. [3]. Велика кількість публікацій стосується питань біоморфології жоржин (Харузина, 1928; Ренард, 1929, 1930; Уайт, 1937; Нагибина, 1940; Петрусевич, 1948; Краснова, 1949; Ященко, 1983; Былов, 1983 й ін.).

Представлено методи агротехніки, вегетативного розмноження та сортооцінки жоржин для різних регіонів європейської частини, Середньої Азії, Азейбарджану, Грузії (Киселев, 1953; Заливский, 1956, 1964; Кротова, Ярина, 1977; Кривченко, Озолин, 1969; Лавриченко, 1985; Шелюто, 1932; Шмыгун, 1952; Немудров, 1962; Barett, 1978; Потоцкая, Ассорина, Денисов, Джакилов, 1984; Яброва-Колоковская, Чочуга, 1958; Базилевская, 1985; Краснова, 1952; Смольский, 1972; Монтрова, 1965; Дороганов, 2000; Гуткин, Прошина, 1970 й ін.) [4].

В Україні вона відома 3 кінця XVIII ст. Починаючи 3 50-х років XIX ст., дослідження розпочали в Національному ботанічному саду iм. М. М. Гришка НАН України. На сьогодні вивченням сортів роду Dahlia займаються Г. Музичук, А. Дорошенко. Колекція нараховує 231 сорт [5]. 
Колекцію жоржин у ботанічному саду Львівського національного університету ім. Івана Франка започатковано в 70-х р. минулого сторіччя. Основне джерело отримання сортового матеріалу - ботанічні сади Білорусі, Польщі, Прибалтики, м. Києва та Москви. На сьогодні колекція жоржин нараховує 107 сортів. Їх вивчення проводять Я. А. Федоровська, А. І. Прокопів [6].

Такі дослідження в Україні досить фрагментарні й актуальними є вивчення та оцінювання декоративних ознак представників роду Dahlia у Кременецькому ботанічному саду. Інтродукцію цього роду розпочато з $2017 \mathrm{p}$.

На підставі головних морфологічних ознак жоржину за класифікацією [7] можна віднести до трав'яних полікарпіків зі спеціалізованими запасальними органами, бульбами на короткому кореневищі. За даними деяких науковців [8, 9], рід об'єднує від чотирьох до 27 видів жоржин, які поширені в гірських районах Мексики, Гватемали, Колумбіï. Характерна особливість жоржини - те, що вона має потовщені запасаючі бульби, у яких у період спокою зберігається великий запас поживних речовин.

Під час аналізу колекційного фонду дотримувалися садової класифікації жоржини, розробленої [10], яку традиційно використовують в Україні, однак назви кольорів та прийняте для них скорочення, а також групи за розміром квітки позначали відповідно до міжнародної класифікації [2]: АА (велетенські) $>25 \mathrm{~cm}$, А (великі) - 20-25 cм, В (середні) - 1520 см, ВВ (дрібні) - 10-15 см, М (мініатюрні) $10 \mathrm{~cm}, \mathrm{BA}$ (кулясті) - $8 \mathrm{~cm}, \mathrm{MB}$ (мініатюрнокулясті) - 5-8 см, Р (помпонні) < $5 \mathrm{~cm}, \mathrm{M}$ (мініатюрні) < 5 см. За висотою рослин у жоржин виділяють п'ять градацій, які умовно позначили так: К - карликові (до $60 \mathrm{~cm}$ ), Н низькорослі (60-80 см), С - середньорослі (80120 см), В - високі (120-150 см) та $Г-$ гігантські (понад $150 \mathrm{~cm}$ ).

\section{Аналіз досліджень цієї проблеми}

Айстрові (Asteraceae) - одна 3 найбільших родин класу дводольних, що включає понад 25 тис. видів та представлена багаторічними травами, напівкущами, кущами, рідше невеликими деревами [3].

Рід жоржина (Dahlia Cav.) нараховує 42 види й понад 15 тис. сортів, які набули популярності як у країнах Європи, так i в Україні. Батьківщина жоржини - Південна
Америка, де аборигени використовували коренебульби жоржини в їжу та в різних ритуалах [11, 12]. Перші описи жоржини 3'явились у XVI ст., вони належали мексиканському лікарю Ф. Хернанделу. У Свропі ця рослина з'явилась у ботанічному саду Мадрида в XVII ст. й була названа на честь ученого Далля - «Далія». Російську назву «Георгина» рослини отримали на честь російського ботаніка німецького походження Георга. Жоржина - декоративна багаторічна рослина 3 великими різнобарвними суцвіттями та потовщеними бульбоподібними коренями коренебульбами [13]. Стебло культивованих рослин пряме, гладке, порожнисте, заввишки 30-200 см, у діаметрі - 1-3 см [14]. Стебла дикорослих видів жоржини можуть сягати заввишки декількох метрів [11]. Листки супротивні, великі, частіше - перисторозсічені, але в деяких сортів бувають і цілісні, можуть різнитися за забарвленням та опушенням. Коренебульби за формою можуть бути округлі й овальні, від світло- до темнокоричневих. Протягом вегетаційного періоду старі коренебульби 35 потовщуються всередину, а нові формуються 3 пагонів цього року. Тривалість їх життя - близько п'яти років [2]. Суцвіття - кошик. У диких видів та культивованих сортів жоржини деяких класів серединні квітки трубчасті двостатеві, дрібні, жовтого або коричневого кольору, а крайові язичкові, безстатеві, різні за забарвленням, формою й розмірами. Діаметр суцвіття коливається від трьох до 30 см [1, 11]. Обгортка кошика чашоподібна, складається 3 двох трьох рядів зелених листочків. Плід сім'янка $[11,12]$.

Мета нашої роботи - аналіз колекційного фонду роду Dahlia Cav. Кременецького ботанічного саду, утримання колекції та подальше впровадження в озеленення.

\section{Матеріал і методи досліджень}

В основу роботи покладено матеріали інтродукційних досліджень 2018 р. Фенологічні спостереження проводили за загальноприйнятою методикою в ботанічних садах [15]. Для оцінки сортового різноманіття колекційного фонду жоржин використовували аналітично-порівняльний метод. В аналізі колекційного фонду дотримувалися садової класифікації жоржини, розробленої М. П. Ященком [10]. Отримані результати опрацьовували на ПК із застосуванням програм Microsoft Office World тa Microsoft Office Excel, 
Оиінка колекційного фонду рослин роду Dahlia Cav. у Кременецькому ботанічному саду

2003, 2007; номенклатуру видів подано згідно 3 Vascular plants of Ukraine [16].

\section{Результати та обговорення}

Колекцію жоржин у Кременецькому ботанічному саду започатковано у 20172018 pp. На сьогодні колекція жоржин нараховує 29 сортів (табл.1).

Згідно з розподілом за групами маємо такі результати:

- два сорти (Karma Bon Bini, Karma Amanda) - змішана група;

- три сорти (Icoon, Sakura Fubuki, Night Queen) - кулясті;

- 11 сортів (Jeanne d'Arc, Gina Lombaert, Mylove, Alfred Grille, Bonne Esprit, Earth, Prestige, Flash, Gold Earth, Mingus Gregory, Karma Corona) - кактусові;

- три сорти (Helga, Aspen, LudwingHelfent) напівкактусові; $-\quad$ два сорти (Hapy go
Heemstede) - група німфейні;

- п'ять сортів (Osaka, Pashmina, Avignon, Jean Marie, Arabian Night) - декоративна група;

- один сорт (Lancresse) - помпонні, один (Tsuki Yori No Shisha) - розсіченопелюсткові, або оленячі роги, і (Vancouver) - група хризантемоподібних.

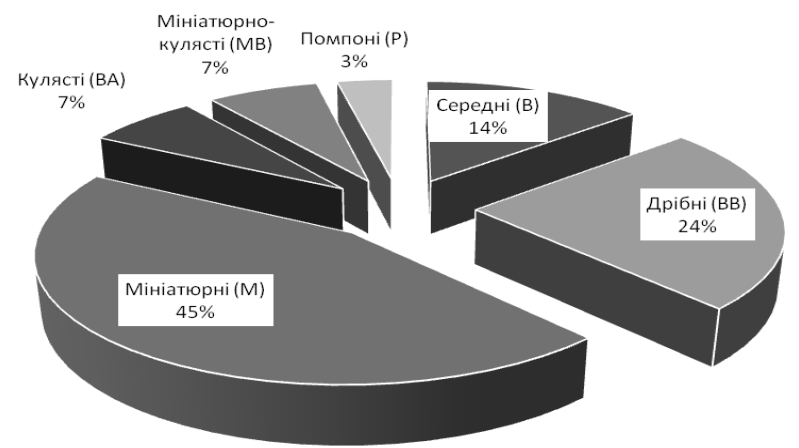

Рис. 1. Спектр репрезентативності садових груп роду Dahlia Cav. за розміром суивіття

Таблиия 1

Біометрична характеристика інтродуцентів роду Dahlia Cav. у Кременецькому ботанічному саду

\begin{tabular}{|c|c|c|c|c|c|c|c|c|}
\hline $\begin{array}{l}\text { № } \\
\text { 3/II }\end{array}$ & Назва сорту & $\begin{array}{c}\text { Колір } \\
\text { квітки }\end{array}$ & 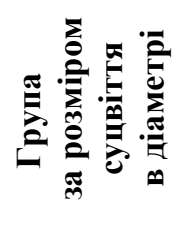 & 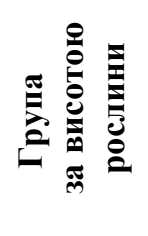 & 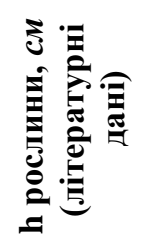 & 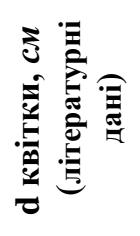 & 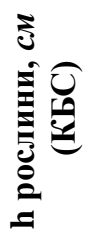 & 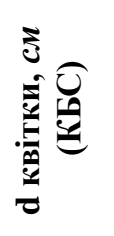 \\
\hline 1 & 2 & 3 & 4 & 5 & 6 & 7 & 8 & 9 \\
\hline 1 & $\begin{array}{c}\text { Karma Bon } \\
\text { Bini }\end{array}$ & $\begin{array}{c}\text { жовто- } \\
\text { червоний }\end{array}$ & M & K & 90 & $10-15$ & 50 & 10 \\
\hline 2 & Karma Amanda & $\begin{array}{c}\text { бузково- } \\
\text { білий }\end{array}$ & M & K & 80 & $10-15$ & 52 & 10 \\
\hline 3 & Icoon & $\begin{array}{c}\text { жовто- } \\
\text { червоний }\end{array}$ & M & K & 100 & $7-10$ & 48 & 10 \\
\hline 4 & Sakura Fubuki & $\begin{array}{c}\text { світло- } \\
\text { фіолетовий }\end{array}$ & BA & $\mathrm{H}$ & $90-120$ & $10-15$ & 70 & $8-10$ \\
\hline 5 & Night Queen & $\begin{array}{c}\text { жовто- } \\
\text { оранжевий }\end{array}$ & M & $\mathrm{C}$ & $110-120$ & 15 & 118 & 10 \\
\hline 6 & Jeanne d'Arc & рожевий & $\mathrm{BB}$ & $\mathrm{C}$ & 110 & $15-20$ & 86 & 12 \\
\hline 7 & Gina Lombaert & $\begin{array}{c}\text { жовто- } \\
\text { рожевий }\end{array}$ & M & K & 100 & $10-15$ & 56 & 10 \\
\hline 8 & My Love & $\begin{array}{c}\text { білий із } \\
\text { жовтою } \\
\text { серединою }\end{array}$ & M & $\mathrm{H}$ & $90-120$ & $10-15$ & 60 & 10 \\
\hline 9 & Alfred Grille & $\begin{array}{c}\text { жовто- } \\
\text { рожевий }\end{array}$ & M & $\mathrm{C}$ & $90-100$ & $15-17$ & 85 & 10 \\
\hline 10 & Bonne Esprit & $\begin{array}{c}\text { рожево- } \\
\text { фіолетовий }\end{array}$ & BA & $\mathrm{C}$ & $90-120$ & $15-20$ & 90 & 9 \\
\hline 11 & Earth & фіолетовий & $\mathrm{M}$ & $\mathrm{H}$ & 100 & 15 & 80 & 10 \\
\hline 12 & Prestige & $\begin{array}{c}\text { рожево- } \\
\text { фіолетовий }\end{array}$ & $\mathrm{BB}$ & K & 135 & 15 & 50 & 12 \\
\hline 13 & Flash & червоний & $\mathrm{BB}$ & K & 120 & 14 & 30 & $10-11$ \\
\hline 14 & Gold Earth & жовтий & $\mathrm{P}$ & $\mathrm{H}$ & 100 & $7-10$ & 65 & $5-6$ \\
\hline
\end{tabular}


Науковий вісник Східноєвропейського національного університету імені Лесі Українки. Серія: Біологічні науки, 2019, 3 (387)

\begin{tabular}{|c|c|c|c|c|c|c|c|c|}
\hline \multicolumn{9}{|c|}{ Закінчення табличі 1} \\
\hline 1 & 2 & 3 & 4 & 5 & 6 & 7 & 8 & 9 \\
\hline 15 & Mingus Gregory & фіолетовий & $\mathrm{M}$ & $\mathrm{C}$ & 120 & $15-20$ & 100 & 10 \\
\hline 16 & Karma Corona & оранжевий & $\mathrm{M}$ & $\mathrm{H}$ & $90-100$ & $15-17$ & 80 & 10 \\
\hline 17 & Helga & червоний & $\mathrm{BB}$ & $\mathrm{C}$ & 90 & $15-20$ & 96 & 12 \\
\hline 18 & Aspen & молочний & $\mathrm{MB}$ & $\mathrm{H}$ & $110-130$ & $15-20$ & 70 & $6-8$ \\
\hline 19 & Ludwing Helfent & оранжевий & $\mathrm{BB}$ & $\mathrm{C}$ & $90-120$ & $10-15$ & 100 & $10-15$ \\
\hline 20 & Hapy go Lucky & $\begin{array}{c}\text { жовто- } \\
\text { оранжевий }\end{array}$ & B & K & 80 & 22 & 50 & 15 \\
\hline 21 & $\begin{array}{l}\text { Glorie van } \\
\text { Heemstede }\end{array}$ & жовтий & MB & $\mathrm{H}$ & $100-120$ & $15-20$ & 75 & 7,5 \\
\hline 22 & Osaka & $\begin{array}{c}\text { жовтий із } \\
\text { білими } \\
\text { кінчиками }\end{array}$ & BB & B & 130 & $10-15$ & 120 & 11 \\
\hline 23 & Pashmina & $\begin{array}{c}\text { рожево- } \\
\text { червоний }\end{array}$ & B & $\mathrm{C}$ & 110 & $20-25$ & 100 & 15 \\
\hline 24 & Avignon & $\begin{array}{c}\text { білий із } \\
\text { фіолетовим } \\
\text { iз лимонною } \\
\text { серединою }\end{array}$ & B & $\mathrm{H}$ & $90-120$ & $20-25$ & 80 & 15 \\
\hline 25 & Jean Marie & $\begin{array}{c}\text { фіолетовий } \\
\text { із білими } \\
\text { кінчиками }\end{array}$ & M & K & 80 & 15 & 56 & 10 \\
\hline 26 & Arabian Night & бордовий & BB & $\mathrm{H}$ & $90-100$ & $15-17$ & 80 & $10-15$ \\
\hline 27 & Lancresse & розовий & $\mathrm{M}$ & $\mathrm{C}$ & $110-130$ & $15-20$ & 100 & 10 \\
\hline 28 & $\begin{array}{c}\text { Tsuki Yori No } \\
\text { Shisha }\end{array}$ & $\begin{array}{l}\text { білий із } \\
\text { жовтим } \\
\end{array}$ & B & $\mathrm{C}$ & $100-110$ & $15-20$ & 100 & 15 \\
\hline 29 & Vancouver & $\begin{array}{l}\text { фіолетово- } \\
\text { білий }\end{array}$ & M & K & 70 & $15-20$ & 60 & 10 \\
\hline
\end{tabular}

За даними дослідження, у колекції жоржин частка середньорослих сортів становить $35 \%$, низькорослих і карликових - по $31 \%$, високі $3 \%$, гігантські сорти на сьогодні відсутні, однак у ході інтродукційних досліджень планується поповнення колекції сортами різних груп (рис. 2).

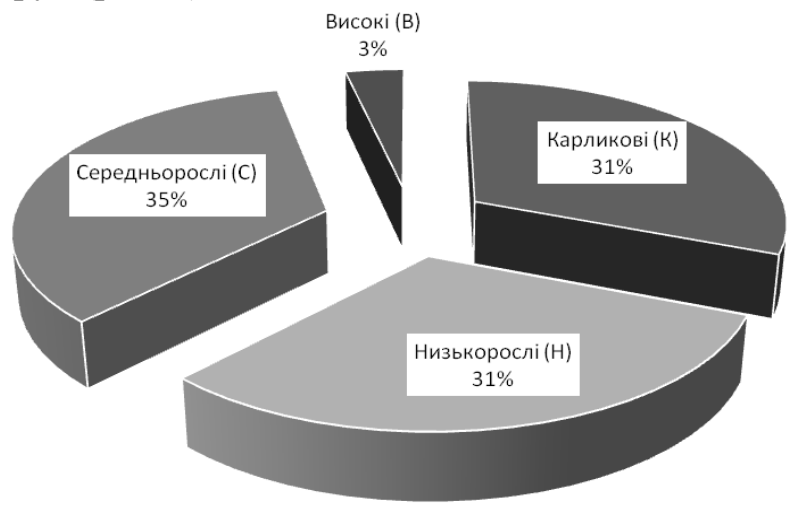

Рис. 2. Спектр розподілу сортів роду Dahlia Cav. за висотою

Згідно зі спектром репрезентативності садових груп роду Dahlia Cav. за розміром суцвіття переважає група мініатюрні $45 \%$, найменшу чисельність має група помпонні - $3 \%$ (рис. 1).
Відображеність сортів колекції за головними кольорами має такі кількісні показники (рис. 3):

$>$ червоний (R) наявний $\mathrm{y}$ трьох культиварів різних садових груп;

$>$ оранжевий $($ Or) - у восьми;

$>$ темно-червоний (DkR) - один сорт;

$>$ лавандовий, фіолетовий (L) - два;

$>$ рожевий $(\mathrm{Pk})$ - два;

$>$ двоколірне забарвлення (Bi) - вісім сортів;

$>$ біле $(\mathrm{W})$ - один;

$>$ жовте (Y) - два;

$>$ темний бленд (LB i DB) - два сорти.

\section{Висновки}

Отже, нами 3'ясовано, що колекція роду Dahlia Cav. в Кременецькому ботанічному саду $\epsilon$ джерелом для подальшої інтродукційної роботи. Досліджені сорти жоржин перспективні для вирощування в умовах культури; біометричні заміри відповідають даним літературних джерел. Поповнення колекції роду Dahlia залишається основним завданням науково-колекційної роботи як способу збереження та збагачення рослинного 


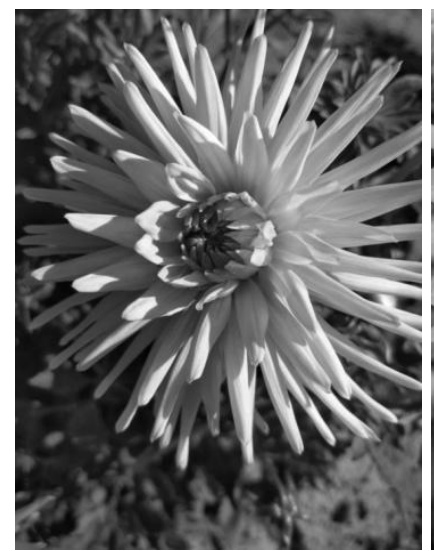

Jeanne d'Arc

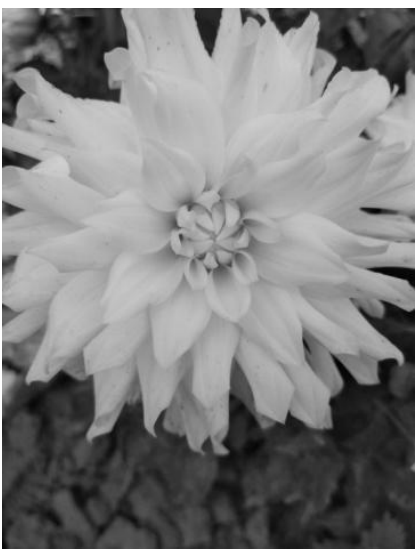

Osaka

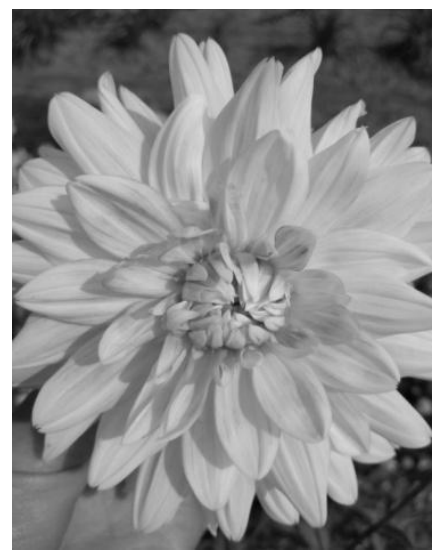

Aspen

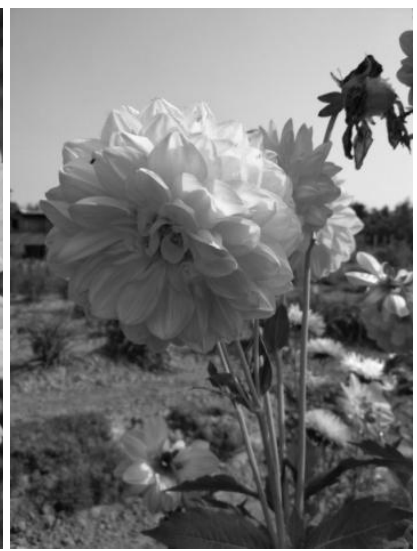

Icoon

Рис. 3. Фото окремих культиварів рослин роду Dahlia Cav. Кременеиького ботанічного саду (автор фото - I. О. Ковальчук)

різноманіття. Використання жоржин під час озеленення території дачної ділянки відіграє значну роль у досягненні запланованих декоративного й естетичного ефектів. Створення жоржинарію - саду 3 жоржин додасть території ділянки неповторної краси та яскравих кольорів, використовуються на зріз для декорування букетів, однак ці рослини не можуть зимувати в грунті, тому потребують зберігання під час зимового спокою.

\section{Література}

1. Classification of Dahlias. The American Dahlia Society; New York, 1979, 67 p.

2. Ilyinska, N. I.; Gontova, T. M.; Matkowski, A.; Sokolova, O. O.; Kichymasova, Ya. S. Isolation of polysaccharide complexes from some inulin-rich Asteraceae and Campanulaceae plants and analysis of free amino acids. Trends in natural products research: young scientists meeting. Olomouc, Czech republic, June 23-25, 2014, pp 58-59.

3. Боса, Н. І. Жоржини; К. П. Дім, сад, город: Київ, 2004, с 30.

4. Худжамова Г. Д. Интродукиия георгин (Dahlia Cav) на Западном Памире Автореф. дис. на соискание ученой степени канд. биол. наук: спец. 03.00.05 «Ботаника». Москва, 2006; с 15.

5. Музичук, Г.; Дорошенко, А. Первинна оцінка сортового різноманіття колекційного фонду роду Dahlia Cav. Національного ботанічного саду ім. М. М. Гришка НАН України. Вісник Львів. ун-ту. Серія біологічна. 2004, 36, с 24-30.

6. Федоровська, Я. А.; Прокопів, А. І. Оцінка сортового різноманіття колекційного фонду роду Dahlia Cav. ботанічного саду Львівського національного університету імені Івана Франка. Науковий вісник НЛТУ України. 2008, 18.12, с 227-231.

7. Серебряков, И. Г. Морфология вегетативных органов высших растений. 1952; с 126.
8. Хессайон, Д. Г. Георгина. Все о иветах в вашем саду. Кладезь: Москва, 1997; с 136-139.

9. Каталог иветочно-декоративных травянистых растений ботанических садов СНГ и стран Балтии. Совет ботан. садов Росии. Центральный ботан. сад АН Беларуси. Є. С. Гальперин: Минск, 1997; с 476.

10. Ященко, Н. П. Георгины. Класификация. Цветоводство. 1985, 6, с 12-21.

11. Ilyinska, N. I.; Gontova, T. M.; Kryukova, Ya. S. The qualitative and quantitative analysis of volatile compounds of the herb of dahlia Nymphaeales of Ken's Flame cultivar. News of Pharmacy. 2015, 4 (84), pp 13-16.

12. Gontova, T.; Ilyinska, N.; Golembiovska, O.; Mashtaler, V. Study of the component composition of phenolic compounds obtained from Dahlia varieties Ken's Flame herb. Der Pharma Chemica. 2016, 8 (18), pp. 455-459.

13. Кичимасова, Я. С.; Гонтовая, Т. Н.; Соколова, О. О.; Ильинская, Н. И. Перспективы изучения содержания аминокислот лекарственных растений и полисахаридных комплексов представителей семейства Asteraceae L. Теоретичні та практичні аспекти дослідження лікарських рослин: матеріали I Міжнар. наук.-практ. Internetконф. м. Харків, 20-21 берез., 2014, с 238.

14. Gontova, T.; Kichymasova, Y.; Ilyinska, N. A study of organic acids obtained from Dahlia Nymphaea-les tubers of the Ken's Flame variety. Actual Questions of Development of New Drugs: $X X$ International scientific and practical conference of young scientists and student, Kharkiv, April 22-23, 2014, s 32.

15. Методика фенологічних спостережень в ботанічних садах СРСР. Вид. АН СРСР: Москва, 1975; c 23.

16. Mosyakin, S. L. Vascular plants of Ukraine. A nomevclaturar checklist. M. G. Kholodny Institute of Botany: Kiev, 1999; p 345. 